\title{
Curiosidade e descoberta; pensamento e experimentação: o Progra- ma Institucional de Bolsas de Iniciação Científica - PIBIC
}

\section{Curiosity and discovery; thinking and experimentation: the Institutional Program for Scientific Initiation Fellowships}

Na Gênese da civilização judaico-cristã está relatado, que o casal original transgredindo a Lei, seduzido pela curiosidade, decidiu experimentar o fruto da arvore da sabedoria. Por este ato, foram penalizados eles e todos os seus descendentes.

Desde então o "limite" persiste, tornando perene o enigma do mundo e exacerbando o desejo e o uso, cada vez mais intenso, da mente humana.

A procura do conhecimento e a compreensão do seu processo de elaboração nos acompanham desde sempre.

Muitos já elegeram estes temas como foco das suas atenções: das classificações aristotélicas na Grécia antiga, distinguindo o natural do artificial, a episteme da techné, às preocupações da Ciência moderna com as armadilhas que os nossos próprios órgãos dos sentidos poderiam nos preparar durante a nossa observação da realidade.

O método científico pretende nos colocar assépticos, "mais expectadores que atores" neste processo, como preconizava Descartes no seu "Discurso do Método".

Esta isenção, tão perseguida, parece cada dia mais difícil de ser atingida.

Idealmente a compreensão do real, careceria então, da percepção de um observador "isento" e de um objeto "único" que interagiriam e se comunicriam dialogicamente, alem de estarem inseridos num tempo histórico e num espaço determinado.

Como é fácil constatar, um ínfimo rearranjo na disposição destas variáveis objetivas e subjetivas, são suficientes para transformar afirmações científicas, evidencias e teses, de categóricas em alegóricas. Expõem desta forma o frágil, todavia legítimo, ideal da objetividade da Ciência. É neste fascinante e instigante cenário que devemos introduzir os nossos jovens estudantes da graduação.

Hoje no Brasil existem mais de 43.000 estudantes de graduação envolvidos nos programas de iniciação científica.

No Instituto Materno Infantil Prof. Fernando Figueira - IMIP, o Programa Institucional de Bolsas de Iniciação Científica - PIBIC, é financiado pelo Conselho Nacional de Desenvolvimento Científico e Tecnológico CNPq, pela Fundação de Amparo à Pesquisa do Estado de Pernambuco - FACEPE e pelo próprio IMIP. Constitui-se em um poderoso instrumento de produção de conhecimento e divulgação dos princípios e métodos científicos. Todas as atividades teóricas e praticas são centradas no estudante e com esta orientação a diretoria de pesquisa tenta estabelecer uma situação de aprendizagem ativa, na qual o bolsista é o próprio construtor do novo conhecimento, acompa-nhado por seu facilitador (orientador), pesquisador mais experiente que lhe serve de modelo e o auxilia na sua tarefa. Também com o intuito de contribuir para a formação sócio-cultural dos estudantes, os trabalhos são desenvolvidos dentro de uma visão institucional holística e humanística, buscando faze-los entender o mundo sob o prisma da ciência, e ao mesmo tempo pretendendo torna-los pesquisadores/cidadãos, críticos, reflexivos e participativos.

A publicação dos seus artigos neste suplemento da Revista Brasileira de Saúde Materno Infantil denota a importância que este periódico atribui à iniciação científica e revela duas importantes ações: a primeira, provocar o desenvolvimento de uma prática da elaboração de artigos científicos de qualidade; a segunda, estimular a eles próprios e aos futuros bolsistas do programa, a necessidade ética e acadêmica de divulgar a sua produção científica.

Para que tudo isto aconteça se faz necessário um comprometimento ideológico com a proposta por parte dos orientadores e dedicação de parte do seu tempo para esta importante atividade de iniciar esses jovens nas certezas e incertezas do pensamento e das experiências, perpetuando assim o desejo humano de conhecer a "Verdade". 